Research

\title{
The failed lumbar puncture
}

\section{Farhad Sahebkar-Moghaddam, MD; and Bruce T. Adornato, MD, FAAN}

$\mathbf{L}$ umbar puncture (LP) is one of the few procedures that neurologists routinely perform and one for which they usually take pride in their performance skills. Rare is the seasoned neurologist who needs fluoroscopy to perform an LP. However, for the neophyte, the successful performance of an LP can be difficult, especially in the uncooperative, immobilized, or large patient.

A common excuse for an unsuccessful LP in a large patient is that the standard (3.5-in) needle is too short. Although a number of articles discuss the technique of performing LPs, ${ }^{1,2}$ we could find no previous studies that actually measured the distance from the skin to the thecal sac.

The distance from the skin to the L3 to L4 intrathecal space was measured in 54 lumbar spine MRI scans that were performed at Palo Alto VA Medical Center for other reasons. Three scans were excluded owing to unknown height and weight information and two because of surgical scar tissue obscuring accurate measurement. The mean age of the cases was 57 years (range 25 to 86 years), and all were male. The distance from the skin to the L3 to L4 intrathecal space was plotted against body mass index (BMI).

The mean distance from the skin to the intrathecal space was2.47 in $(62.8 \mathrm{~mm})$ and median

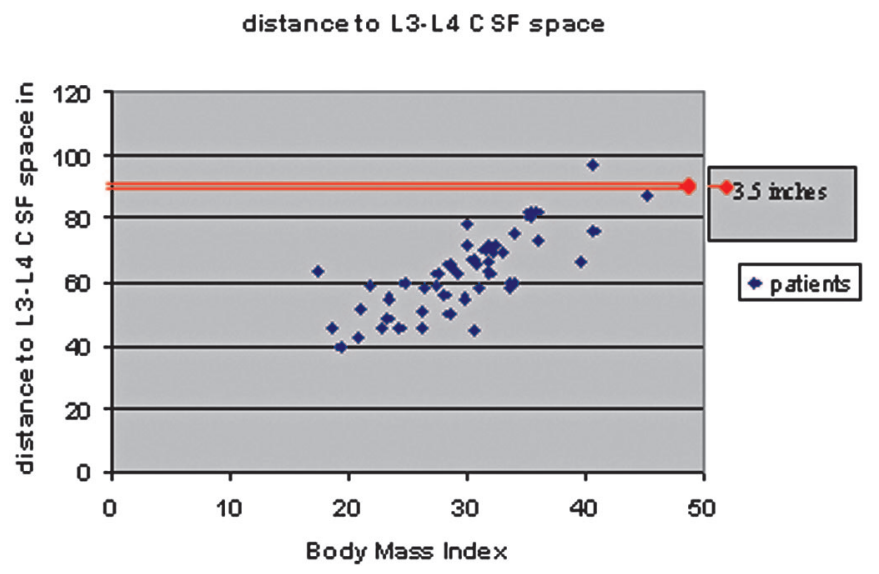

Figure. The distance from the skin to the L3 to L4 intrathecal space was measured in 54 lumbar spine MRI scans that were performed at Palo Alto VA Medical Center. The distance from the skin to the L3 to L4 intrathecal space was plotted against body mass index.

distance 2.44 in $(62 \mathrm{~mm})$. The mean BMI was $29.8 \mathrm{~kg} / \mathrm{m} 2$ (range 17.3 to $40.7 \mathrm{~kg} / \mathrm{m} 2$ ) (figure). With exception of one scan in an individual with BMI of $40.6 \mathrm{~kg} / \mathrm{m} 2$, no skin-tointrathecal distance was $>3.4$ in.

A 3.5-in spinal needle is long enough to enter the lumbar space in almost all patients (97\%) and, in our experience, all male patients with BMI of $<40 \mathrm{~kg} / \mathrm{m} 2$. Whether or not this guideline applies to females, potentially with a different adipose pattern, we have not yet determined.

Longer needles, usually 4 inches in length, can be used in exceptionally large patients, but there is greater risk of misplacement, due to their tendency to bend.
We conclude that when the neurologist experiences difficulty in completing a successful LP, what is probably too short is not the needle but the experience of the clinician. We agree with the view that "if the physician fails to obtain any fluid at two different interspaces, sometimes another physician will be successful." ${ }^{3}$ Only very rarely will a needle longer than 3.5 in be necessary.

\section{References}

1. Livingston KE. Technic of lumbar puncture. N Engl J Med 1972;287:724.

2. Petito F, Plum F. The lumbar puncture. N Engl J Med 1974;290:225-227.

3. Fishman RA. Cerebrospinal fluid in diseases of the nervous system. 2nd ed. Philadelphia: Saunders, 1992. 


\title{
Neurology
}

\author{
The failed lumbar puncture \\ Farhad Sahebkar-Moghaddam and Bruce T. Adornato \\ Neurology 2005;64;E24 \\ DOI 10.1212/01.wnl.0000164849.90985.2f
}

This information is current as of April 11, 2005

\section{Updated Information \&}

Services

\section{Supplementary Material}

References

Permissions \& Licensing

Reprints including high resolution figures, can be found at: http://n.neurology.org/content/64/7/E24.full

Supplementary material can be found at: http://n.neurology.org/content/suppl/2007/04/02/64.7.E24.DC1

This article cites 2 articles, 0 of which you can access for free at: http://n.neurology.org/content/64/7/E24.full\#ref-list-1

Information about reproducing this article in parts (figures,tables) or in its entirety can be found online at:

http://www.neurology.org/about/about_the_journal\#permissions

Information about ordering reprints can be found online:

http://n.neurology.org/subscribers/advertise

Neurology ${ }^{\circledR}$ is the official journal of the American Academy of Neurology. Published continuously since 1951, it is now a weekly with 48 issues per year. Copyright . All rights reserved. Print ISSN: 0028-3878. Online ISSN: 1526-632X.

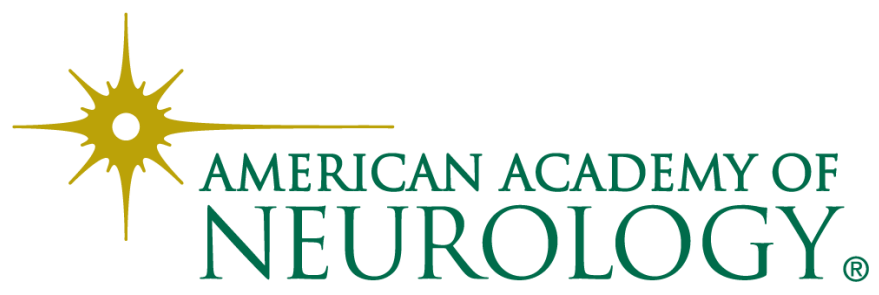

